3. Bila A., Lindgren D. Fertility variation in Milletias tuhlmannii, Brachystegia spiciformis, Brachystegia bohemii and Leucaena leucocephala and ist effects on relatedness in seeds. Forest genetics. 1998. Vol. 5 (2). P. 119-129.

DOI https://doi.org/10.30525/978-9934-26-184-8-16

\title{
СТАЦІОНАРНІ ДОСЛІДЖЕННЯ РУБОК ДОГЛЯДУ В СОСНОВИХ ДЕРЕВОСТАНАХ
}

\author{
Лавний В. В. \\ доктор сільськогосподарських наук, професор, \\ професор кафедри лісівництва \\ Національний лісотехнічний університет Украӥни \\ м. Львів, Україна \\ Петер Шпатгельф \\ професор факультету лісу і довкілля \\ Університет сталого розвитку Еберсвальде \\ м. Еберсвальде, Німеччина \\ Вицега Р. В. \\ кандидат сільськогосподарських наук, доиент, \\ дочент кафедри лісової таксації та лісовпорядкування \\ Національний лісотехнічний університет України \\ м. Львів, Україна
}

Формування біологічно стійких та високопродуктивних деревостанів вимагає своєчасного проведення в них лісогосподарських заходів, зокрема рубок догляду. Сучасні нормативи не повною мірою регламентують основні критерії щодо проведення рубок формування та оздоровлення лісів і не завжди враховують особливості окремого деревостану. Удосконалення нормативної бази вимагає сучасних глибоких наукових досліджень 3 70 
урахуванням інноваційних підходів, які отримали широке впровадження на виробництві передових країн. Це забезпечило б можливість дослідити особливості процесів росту деревостанів в динаміці. Здебільшого такі дослідження виконують на стаціонарних лісових об'єктах.

3 огляду на вказане вище науковцями Національного лісотехнічного університету України у співпраці з науковцями Університету сталого розвитку Еберсвальде у рамках міжнародного наукового гранту RESILPINE ${ }^{1}$ закладено наукововиробничий стаціонар у Борщовицькому лісництві (кв. 20, вид. 3) державного підприємства «Львівське лісове господарство». Об'єкт створено 3 метою досліджень впливу різних методів та інтенсивностей рубок догляду на стан й продуктивність соснового деревостану. Стаціонар розміщено в 19-річному сосновому насадженні загальною площею 9,0 га в умовах вологого грабоводубово-соснового сугруду. У межах таксаційного виділу згідно методики виділено 5 незалежних секцій розміром 0,4 га кожна $(80$ м $\times 50$ м). Схему розміщення секцій представлено на рис. 1.

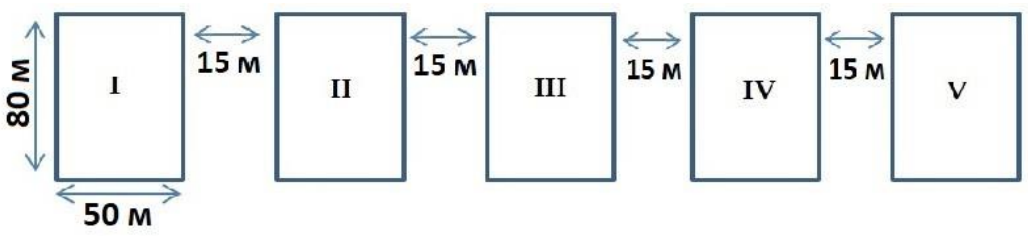

\section{Рис. 1. Схема розміщення секцій на науково-виробничому стаціонарі}

Всі секції розміщені послідовно одна за одною, але при цьому між ними залишено буферну зону (15 м). Це дає змогу уникнути впливу бокового освітлення межових дерев від сусідніх секцій.

${ }^{1}$ This study was undertaken within the framework of the „RESILPINE“ project, which was financially supported by the German Federal Ministry of Food and Agriculture (BMEL) (Grant number: 28I-034-01). 
На першому етапі на кожній секції зроблено відмежування секцій в натурі, суцільну нумерацію дерев фарбою та вимірювання їх лісівничо-таксаційних показників. Загалом обліковано та обміряно 4870 дерев.

Другий етап передбачав проведення лісогосподарського заходу (рубки догляду прочищення). 3 цією метою були позначені дерева, що підлягають вирубуванню. Кількість таких дерев на кожній з секцій визначено індивідуально, залежно від методу та інтенсивності рубки догляду. При цьому на першій секції не запроектовано жодних господарських заходів. Цю секцію залишено у якості контролю. На інших секціях запроектовано рубки з різною інтенсивністю та різним методом (друга секція інтенсивність рубки $20 \%$, низовий метод; третя секція інтенсивність рубки $40 \%$, низовий метод; четверта секція інтенсивність рубки $20 \%$, верховий метод; п’ята секція інтенсивність рубки $40 \%$, верховий метод).

На першій секції насадження характеризується $\mathrm{I}^{\mathrm{b}}$ класом бонітету. У складі деревостану переважає сосна звичайна (10 одиниць) та присутні як домішка ще дуб звичайний, граб звичайний, осика та дуб червоний. На другій секції у складі деревостану також переважає сосна звичайна (10 одиниць), проте тут росте по кілька дерев низки інших деревних видів. Насадження характеризується високим класом бонітету $\left(\mathrm{I}^{\mathrm{b}}\right)$ та високою відносною повнотою $(0,88)$. Для забезпечення запроектованої інтенсивності рубки (20 \%) відібрано 349 дерев. Здебільшого це відсталі у рості екземпляри сосни звичайної. Насадження третьої секції характеризуються складом 9Сз1Лп та участю в складі інших порід. Заплановану дуже сильну інтенсивність рубки (40 \%) забезпечує вирубування 440 дерев, 3 яких - 363 дерев сосни звичайної, 45 дерев - липи дрібнолистої, 18 дерев - верби козячої, 6 дерев - берези повислої та по 1 дереву інших деревних видів. Четверта пробна площа характеризується, як і попередні пробні площі, перевагою у складі сосни звичайної, високим класом бонітету $\left(\mathrm{I}^{\mathrm{b}}\right)$ та середньою повнотою $(0,78)$. Тут у рубку призначено 183 дерева (здебільшого панівні та надпанівні), 3 яких 167 дерев сосни звичайної, що забезпечує інтенсивність рубки $20 \%$. На п'ятій секції у складі деревостану також домінує 72 
сосна звичайна $з$ домішкою берези повислої і незначної кількості дерев інших видів. Склад насадження 9Сз1Бп + інші деревні породи. У рубку призначено 298 дерев, з яких 223 дерева - сосна звичайна, 40 дерев - береза повисла, 11 дерев - осика, 9 дерев верба козяча, 8 дерев - липа дрібнолиста, 4 дерева - дуб червоний, 2 дерева - клен гостролистий і 1 дерево - черемха. Загальний об'єм призначених у рубку дерев становить 39\% від загального запасу деревостану. Така дуже сильна інтенсивність прочищення на третій та п'ятій секціях планується для демонстрування студентам та зацікавленим громадянам впливу світлового режиму на ріст і розвиток дерев сосни звичайної. Загалом на наукововиробничому стаціонарі у рубку призначено 1270 дерев.

Із сукупності дерев, що залишаються рости відібрано кращі (цільові) дерева. Для таких дерев зроблено обрізування нижніх гілок до половини висоти дерева. Так, на другій секції відібрано 67 цільових дерев сосни звичайної, на третій секції - 66 дерев сосни звичайної та 6 дерев дуба звичайного, на четвертій секції 66 дерев сосни звичайної та 3 дерева дуба звичайного і на п’ятій секції - 65 дерев сосни звичайної. Кращі дерева ми намагалися розташовувати більш-менш рівномірно на площі секції.

Таким чином на науково-виробничому стаціонарі запроектовано проведення прочищення 3 різними варіантами інтенсивності та методу рубки догляду. Це забезпечить на кожній секції різні світловий режим окремих дерев, горизонтальну i вертикальну структуру, диференціацію дерев за діаметром та висотою. Довготривалі наукові лісівничо-таксаційні дослідження дозволять отримати вичерпну інформацію про особливості часової динаміки росту соснових деревостанів за різних методів та інтенсивностей рубок догляду. Отримані результати будуть служити підгрунтям для розробки практичних рекомендацій щодо проведення рубок догляду в соснових деревостанах 3 урахуванням типів лісу та глобальних змін клімату. 